\title{
JOHN FORD E OS HERÓIS DA TRANSIÇÃO NO IMAGINÁRIO DO WESTERN
}

ISMAIL XAVIER

\section{RESUMO}

$\mathrm{O}$ artigo analisa o percurso do western de John Ford a partir de No tempo das diligências (1939), Rastros de ódio (1956) e O homem que matou o facínora (1962), obras que compõem uma trilogia voltada para distintas etapas da conquista do Oeste, ensejando a discussão sobre a relação do cineasta com a mitologia do gênero; de filme a filme, o estatuto do herói se desloca em consonância com uma crescente reflexividade que interroga os pressupostos da formação nacional.

PALAVRAS-CHAVE: John Ford; western; estatuto do herói; cinema americano.

\section{ABSTRACT}

This article focuses on John Ford westerns, dealing more specifically with Stagecoach (1939), The searchers (1956) and The man who shot Liberty Valance (1962), films that form a trilogy engaged in the representation of distinct stages of the conquest of the West, allowing for a discussion on Ford's relationship with the mythology of the genre; from film to film, the hero's status changes in consonance with an increasing reflexivity that interrogates the premises of the national formation.

KEYWORDS: John Ford; western; status of the hero; American cinema.

[1] Arrigucci Jr., Davi. “Entre a lenda e a história", Suplemento MAIS, Folha de S.Paulo, 7/5/1995.
O meio moderno, ao se apropriar do passado recente, projeta-o, mediante o distanciamento épico, à dimensão idealizada da lenda ou do mito, mas não pode evitar a ebulição dos fatos ainda recentes, que afloram de algum modo no passado reconstruido. A zona de intersecção do fato com a lenda éo espaço privilegiado do faroeste; John Ford éo poeta desse espaço.

Davi Arrigucci Jr. ${ }^{1}$

O western, como ficção literária e gênero do cinema, construiu um imaginário que transfigura uma experiência histórica em termos de uma épica que trabalha a conquista territorial como um eixo central da formação dos Estados Unidos, no plano da ordem social e dos valores fundamentais que prepararam a nação no sentido moderno. Essa formação, como foi o caso de outros países emergidos de situações coloniais, envolveu processos migratórios os mais variados e a prolongada guerra de extermínio contra as populações 
nativas que fez dessa expansão um processo representado, grosso modo, do ponto de vista dos vencedores.

Se a conquista do Oeste marcou a dinâmica social e econômica depois da independência, o imaginário que aí se constituiu não se reduz à dimensão bélica da conquista, ao domínio da natureza e à apropriação de suas riquezas, mas inclui também um rebatimento simbólico que deu nova inflexão para um nacionalismo da singularidade de caráter forjada na construção do "novo homem" revigorado por tais desafios, apto a superar as "doenças civilizacionais" que teriam acometido uma Europa permeada de guerras de religião e perseguições das quais os puritanos fugiram em direção à terra prometida. A conotação bíblica presente nesse imaginário se traduziu, por exemplo, na noção de Destino Manifesto, que supõe o Novo Mundo como um território destinado aos brancos europeus, seus ocupantes legítimos. Posse inelutável que ganha especial inflexão na ideia daquele caráter nacional forjado em estreito contato com forças tectônicas que catalisam um novo modo de ser que, no limite, define uma espécie de Adão americano a cumprir a vocação de transformar o deserto - uma terra virgem supostamente desabitada ou em mãos que devem ser excluídas - em jardim².

Estes são temas presentes na história do western como gênero popular de filmes B que não excluiu cineastas de maior talento que assumiram uma forma narrativo-dramática embebida desse imaginário, mas trabalharam de modo original, com um senso especial dessa dinâmica cultural presente na experiência do frontier, o espaço mítico de confrontos que, segundo o mito, regeneram virtudes perdidas; posto avançado, zona liminar de passagem em que se constitui o contato com a alteridade, o imaginário das aventuras possíveis, a celebração dos valores da guerra e da potência individual de heróis que vivem uma condição anterior à constituição de um Estado-nação que vem se constituir como instância ordenadora que requer o exercício do monopólio da violência.

Nesse sentido, o western se inscreve no campo das "ficções de fundação", usando aqui a noção de Doris Sommer3. Nestas, dramas privados e questões públicas se entrelaçam, Eros e Polis se unem; a paixão amorosa, o desejo heterossexual de um casal protagonista, se funde a uma teia de acontecimentos históricos de modo que o seu destino condensa, como uma sólida figura, o destino nacional, dado o pressuposto de que esses dois planos de experiência expressam uma base comum de valores, revelam uma sintonia que alia o percurso dos personagens e os conflitos da história.

Síntese do mito da idade heroica dos fundadores, o gênero trouxe algo mais do que a expressão de tal mitologia, dando lugar, na sua evolução, a obras mais complexas que não só incorporaram os motivos
[2] Ver Smith, Henry Nash. Virgin land: the American West as symbol and myth. Nova York:Vintage Books, 1950 .

\footnotetext{
[3] Sommers, Doris. Fiç̧ões de fundação: os romances nacionais da América Latina. Belo Horizonte, UFMG, 2004.
} 
[4] Ver Turner, Frederick Jackson. The frontier in American history. Nova York: Holt, Rinehart and Winston, 1962. Para uma discussão da hipótese de Turner e suas implicações, ver Slotkin, Richard. Gunfighter nation: the myth of the American frontier in twentieth-century America. Nova York: Harper Perennial, 1993, pp. 29-62. das fiç̧ões de fundação como também tensionaram seu universo com tramas e personagens que convidam à reflexão sobre os valores efetivamente presentes, tanto naquele passado de formação quanto no presente em que se insere a produção dos filmes. Tomo aqui o cinema de John Ford como referência e destaco três de suas melhores obras, No tempo das diligências (Stagecoach, 1939), Rastros de ódio (The searchers, 1956) e O homem que matou o facinora (The man who shot Liberty Valance, 1962), para apontar como formam uma trilogia que permite discutir a relação entre o cineasta e os pressupostos dessa formação nacional. Ou seja, permite esclarecer o modo como ele lança indagações que, sem dissolver a feição heroica de seus protagonistas e seus códigos marciais, sugerem uma articulação problemática entre o imaginário que celebra o indivíduo como pilar, instância fiadora de um ideal de sociedade, e as condições concretas de sua ação marcada por uma rede de interesses e relações sociais de poder.

A trilogia aqui em pauta compreende filmes realizados em distintas décadas, cada qual apresentando uma forma própria de tratar a etapa vivida pelas personagens no processo geral de conquista e modernização:Stagecoach focaliza o momento por excelência da expansão territorial entendida como um percurso ininterrupto do "ir adiante" reativado pela disponibilidade de novos frontiers nos vastos espaços do Far West (incluído o que era território mexicano), disponibilidade que, segundo a hipótese de Jackson Turner, formulada em 1893, havia sido essencial para a vitalidade desse processo de formação nacional, seja como condição de desenvolvimento econômico, seja como lugar de revigoramento do caráter pelo mergul ho e isolamento num mundo de embates violentos visto como prelúdio de novos ciclos de avanço da civilização ${ }^{4}$. The searchers desloca a ênfase para a questão da guerra de extermínio e o papel do ódio racial neste processo de crescente domínio do território e estabilização de uma ordem social alimentada pela utopia de uma civilização artesanal agrária de pequenas propriedades, seguindo a lei de distribuição de terras aprovada em 1862, o Homestead Act, que, mais efetivo por algumas décadas, não atingiu suas metas, atropelado pela própria dinâmica da modernização industrializante e de concentração de capitais. The man who shot Liberty Valance traz o West em seu momento de domínio territorial mais avançado, e sua ênfase dramática recai sobre a superação da instabilidade vivida por uma comunidade ainda marcada pelo imperativo da passagem do domínio absoluto das armas à nova ordem de relações mediadas por dispositivo legal mais estável.

Nos três filmes, ressalvada sua distinta inscrição no tempo, o traço comum é a tematização da passagem da lei do sangue para a lei da Polis; da cadeia da vingança centrada nos assuntos de família ou no despotismo patriarcal de criadores de gado, para a conformação da 
justiça mediada por um quadro institucional apoiado na constituição do Estado nacional.

Vale nestes casos um esquema romanesco que é uma versão moderna (e popular) do que vemos na tragédia grega, em especial na trilogia de Ésquilo - a Oresteia - que tematiza essa passagem quando se completa a travessia de Orestes. Na terceira parte da trilogia (Eumênides), a deusa Atena instaura no Olimpo o tribunal que faz prevalecer a lei da Polis e absolve o herói da condenação pela lei do sangue, ou seja, da perseguição das Fúrias, as guardiãs das leis da família que tensionaram a etapa anterior da travessia.

Os três filmes, na forma de compor o drama e tramar o seu desfecho, se posicionam de modo original em face dos paradigmas que se combinam e se sucedem no mito da conquista. Ao mesmo tempo, compõem dois movimentos que vale antecipar: (1) há um gradativo deslocamento do herói que encarna os valores marciais - o gunfighter - e seu modo de cumprir um papel que tem enorme relevância no contexto em que vive seus combates, mas é traço comum ele se destinar a uma nova condição que o afasta do convívio com os representantes da comunidade que se mostra em formação, marcando o paradigma do herói que, embora pilar de um salto importante em direção à ordem futura, não terá lugar nela, dada a tensão que exibe com os valores assumidos como centrais no marco das relações que vão construir a nova sociedade; (2) a trilogia caminha em direção a uma crescente reflexividade, cada filme, a seu modo, deixando interrogações que rebatem sobre pontos fundamentais do imaginário do western, sendo que, dos três, O homem que matou ofacínora é o metawestern por excelência, construindo a narrativa pela mediação da voz de um herói fundador que vem revelar os fatos subjacentes à lenda, de modo a colocar em discussão o próprio sentido do gênero e suas implicações.

\section{A IDADE DA INOCÊNCIA: O NEW DEAL DO HERÓI ROMÂNTICO}

Stagecoach trabalha a figura do herói marginal, Ringo Kid (John Wayne quando jovem), personagem clássico movido por um projeto de vingança que traz inflexão especial à trama. De início, tal projeto é motivo da atenção do xerife da cidade de Tonto, que, ao receber a notícia de que Ringo fugiu da prisão, decide partir na diligência para Lordsburg com intuito de prendê-lo. Seu objetivo é evitar o esperado confronto, nessa cidade, entre Ringo e os irmãos Plummer, que mataram seu irmão e conspiraram para que ele fosse preso ainda muito jovem.

A viagem dessa diligência, eixo da narrativa, faz convergir vários pontos de tensão dramática que mobilizam o espectador, destacado o que incide sobre todos os personagens: a ameaça trazida por Jerônimo, o chefe apache que lidera uma revolta ao recusar o confinamento na 
reserva, tornando-se a figura extracampo de que se fala de forma obsessiva na abertura do filme, seja no forte militar ou na pequena cidade. $\mathrm{Na}$ travessia, os apaches serão o foco onipresente de tensão para os passageiros que formam a pequena comunidade que se aperta na diligência e vive esta condição estrutural do frontier. A notícia da mobilização dos índios coincide com a chegada da diligência vinda do Leste a Tonto, uma escala em sua jornada. A ocupação do território pelos brancos é descontínua, instável, e a questão-chave no avanço da diligência é a decisão de cada passageiro sobre se deve ou não continuar viagem após a notícia da ameaça. Uma patrulha do exército vai escoltá-los, diminuindo o risco a enfrentar na travessia do Monument Valley, cuja iconografia singular dá ressonância ao drama e ao senso de presença iminente dos índios, que permanecem quase sempre "fora da vista", até o fim da viagem, visíveis apenas numa cena em que observam do alto a passagem da diligência. No mais, são as mensagens através dos seus sinais de fumaça.

A primeira sequência oferece o quadro geral e apresenta a galeria de tipos que forma a pequena comunidade que vai se apertar na diligência diminuta e revelar seu caráter, valores e atitude, potencializados por essa situação-limite.Temos o xerife; o condutor da diligência (polo da comédia, figura popular simpática a Ringo); a esnobe Lucy, moça do Leste a caminho do reencontro em Lordsburg com o marido, capitão do exército mobilizado na guerra; o jogador de pôquer, Hatfield, com ares de aristocrata sulino afetado pela derrota na Guerra Civil, que se aproxima de Lucy quando esta sai da diligência em Tonto, faz a cortee termina por embarcar para "protegê-la". Nessa relação, a mise-en-scène se faz de jogos de olhar, tal como na apresentação dos que estão sendo expulsos da cidade, indesejáveis que a Liga da Lei e da Ordem obriga a embarcar, a prostituta Dallas e Doc Boone, o médico alcoólatra que desfila com ela pelas ruas enfrentando com humor o preconceito. Peacocké o discreto vendedor de uísque que veio com a diligência e decide continuar, para felicidade do doutor; Gatewood é o banqueiro que embarca às pressas quase na saída da cidade, já exibindo arrogância e atitudes suspeitas, funcionando como metáfora de uma elite financeira de que se deve desconfiar (estamos na era Roosevelt, em 1939). Ringo não é passageiro regular e só aborda a diligência quando já afastada da cidade, após o plano simbólico que marca a passagem da "civilização" à "natureza selvagem", opondo o marco-limite do casario e o espaço mítico do Monument Valley. Pensando estar com controle da situação, atira para o alto e exibe seu rifle, mas é surpreendido pela voz de prisão do xerife e pela aparição, logo atrás, da escolta do exército. Entrega a arma e se instala a bordo sentado no chão.

A pequena comunidade segue a viagem, cada qual representando uma forma de vivência dofrontier, de modo a que se componha o mo- 
saico de comportamentos de classe capaz de gerar uma reflexão sobre o perfil social do novo país e a relação efetiva de cada personagem em sua distância diante da pauta de valores igualitários proclamada 5 . Prevalece a dinâmica de preconceito e discriminação instalada pelas figuras da "boa sociedade" que olham com reservas o comerciante de uísque e o doutor, rejeitam Ringo e abominam a presença de Dallas. Nessa relação entre grã-finos e marginalizados, as duas paradas da diligência definem o sentido maior da viagem.

$\mathrm{Na}$ primeira, o militar anuncia que recebeu novas ordens e não mais seguirá a diligência, que ficará por sua conta e risco. Comandados pelo xerife, os passageiros devem votar pela continuidade ou não da viagem. Decidem prosseguir.Após a votação, é hora de compor a mesa para o repasto. Há uma regra tácita: a exclusão de Dallas. No entanto, esta não se consuma de imediato porque Ringo, que não a conhece, a convida para sentar a seu lado, gerando olhares indignados, em especial o de Lucy, que, na cabeceira da mesa, humilha a moça expulsa da cidade com seu nariz empinado. Dallas baixa os olhos. É emblemático aqui o clássico campo-contracampo que constrói o momento da rejeição, acentuando a pressão do olhar de Lucye a modéstia culpada de Dallas. O jogador usa seu know-how de etiquetas e convida a moça e seus parceiros "legítimos" a se sentar na outra ponta da mesa, "perto da janela, onde está mais fresco". Consagra-se na imagem a oposição entre os dois grupos, a distância e os olhares valendo como condenação e isolamento que radicaliza o que já se configurava na disposição dos corpos na diligência e no diálogo cheio de farpas entre o médico e o sulista, pontuado pelo discurso sentencioso do banqueiro.

O filme compõe uma polaridade ética que tem fundo democrático e ganha forma cênica dentro do código do melodrama, valorizando a autenticidade e a boa disposição igualitária dos destituídos de status social. Constrói-se a relação de empatia com Dallas, Ringo e o médico alcoólatra, que mais tarde vão confirmar suas virtudes e neutralizar o estigma lançado pelas figuras que a mise-en-scène enquadra numa moldura crítica.

Estabelecida a polaridade entre esnobes e excluídos, a diligência segue viagem até alcançar a estalagem dos mexicanos simpáticos que exibem outras alternativas de convivência, incluído o casamento com moças indígenas, sem problemas. No entanto, há limites no poder de relativização trazido por esse exemplo, pois eles, de certo modo, não escapam a uma dose de estereótipo. Na estalagem, Lucy recebe, do mexicano, a notícia de que seu marido está gravemente ferido, e a crise que então se desencadeia - de novo, em chave melodramática - revela que ela está grávida (ninguém notara antes!) e precisa socorro para um parto urgente, momento em que o doutor consegue se afirmar. Ajudado pelos amigos, sai da embriaguez, entra em forma, exerce a sua
[5] Esse aspecto central do filme se inspira no conto de Guy de Maupasant "Bola de sebo", em que há a dissecação dos comportamentos de classe, notadamente a discriminação de uma prostituta constrangida por um grupo de passageiros burgueses $e$ aristocratas que viajam numa carroça em território francês ocupado pelos alemães em plena Guerra Franco-Prussiana. Há a mesma dinâmica de travessia e parada em estalagem. 
competência e, assistido por Dallas, realiza com sucesso a operação: o bebê nasce com as conotações evangélicas de um milagre e é nos braços de Dallas que é posto em foco para a contemplação admirada de todos. Detalhe essencial: a retórica do olhar tem aqui seu momento decisivo quando vemos a expressão de Ringo a observar Dallas com o bebê, sinal de uma vocação para a maternidade, virtude que desperta nele o projeto da futura união para viver num rancho mais a oeste, além-fronteira, projeto para o qual ele a convida em cena seguinte, primeira manifestação do herói na direção de encarnar a figura mítica do Adão americano que faz avançar a utopia pastoral de domesticação da natureza, a transformação do deserto em jardim, no caso só possível além-fronteira, em território (até então) mexicano. O lance final de Stagecoach será a promessa de realização desse projeto, tornada possível pelo gesto do xerife.

Após a segunda parada da diligência, a retomada da travessia é mais dramática, opondo o novo membro da comunidade, gerador de promessa de vida, e a precipitação da ameaça dos índios que se consuma no grande confronto que seria fatal para o grupo não fora um motivo basilar do gênero: a chegada providencial da cavalaria. Nem todos se salvam: Peacock e Harfield são mortos. Os vivos são escoltados até Lordsburg, onde cada qual seguirá o destino próprio ao que se definiu como seu caráter. Ringo consegue consumar a sua vingança no modo heroico requerido, eliminando os três irmãos Plummer num único duelo em plena rua principal e entregando-se em seguida ao xerife. Este, com a cumplicidade do doutor, agora com mais autoridade em sua filosofia, o libera para o encontro com Dallas. O casal parte numa charrete rumo à sua utopia.

De um lado, segundo o mito da formação, este movimento sugere a inserção do jovem casal na categoria dos tipos edênicos que a mitologia do western potencializou: o foragido da cadeia e a prostituta acabam por se mostrar a melhor encarnação dos bons princípios, dado que os leva a buscar, no final, um espaço de vida simples junto à natureza. Ringo Kid, ao encarnar a figura da inocência não de imediato reconhecida, cumpre um trajeto de provas que se completa na sua ação comogunfighter cujo papel é "limpar a cidade" e preparar o avanço da ordem, mas cujo percurso de lutas, embora justificado, está no terreno da lei da vingança: a prisão parece ser o seu destino, mas a avaliação do xerife, em que o homem cordial, na acepção de Sérgio Buarque de Hollanda, prevalece sobre o homem da lei, o libera para um exílio desejado. O jovem herói da transição, neste filme, ainda poderá cumprir um papel positivo indo adiante em direção ao novo frontier ao lado da mulher que, vítima do moralismo, depurou suas virtudes e simbolizou a maternidade no momento decisivo. Redimidos, podem ser vistos como prontos para a missão pioneira que faz convergir o seu destino e o ideal da formação nacional. 
De outro lado, embora a ficção de fundação aqui se ajuste plenamente ao mito da conquista do Oeste no eixo da hipótese de Turner (o essencial é "ir adiante" na conquista de novos territórios), o que se configurou na vida das duas cidades, pontos de partida e de chegada da travessia, está longe de compor um exemplo de promessa regeneradora do caráter que seria próprio, segundo o mito, da vivência no frontier. O "ir adiante para montar um posto avançado da civilização" se desestabiliza como enunciado de uma teleologia, pois nem as cidades nem a comunidade forçada que se acotovela na diligência sustentam, por ora, a positividade de tal avanço. Funcionam mais como evidência de iniquidades que se deslocam juntamente com a conquista, algo que inspira a ironia de Doc Boone quando, após se despedir de Ringo e de Dallas, enuncia, sem esperanças teleológicas, que eles "estão livres das bênçãos da civilização", sendo em seguida convidado pelo xerife para tomar uns drinques. A que responde: "Só um".

\section{A CENA PRIMITIVA DO RACISMO SECULAR:}

\section{A GUERRA PARTICULAR DO HERÓI RESSENTIDO}

Em Stagecoach, no momento do confronto com os índios, um gesto extremo de Hatfield, não por acaso, retoma uma imagem emblemática de Onascimento de uma nação (1915), o paradigma radical das ficções de fundação de cunho racista no cinema americano. No entanto, o gesto de Hatfield se faz dentro de outra moldura, pois a figura do aristocrata sulino - tão decantada no filme de D. W. Griffith e depois em $E 0$ vento levou (Victor Fleming, 1939) - recebe aí um olhar crítico que marca a diferença de John Ford em face do mestre e a sua oposição à elegia pastoral referida ao Sul presente na superprodução épica que lhe é contemporânea. Em Onascimento de uma nação, o pai e a irmã do herói que comanda a luta pela restauração da supremacia branca contra a "ameaça" dos negros liberados pela Guerra Civil estão presos numa choupana cercada pelos "inimigos". No desespero, o pai, em transe, agarra a filha e encosta a arma em sua cabeça — antes vê-la morta do que sujeita à "luxúria" dos negros. Tal gesto é tomado como ponto extremo dos dramas vividos pelo patriarca racista, havendo um convite para que nos identifiquemos com ele e sua demonstração de fidelidade ao princípio da pureza racial. O socorro chega a tempo e o gesto não se consuma graças à intervenção de um grupo liderado pela Ku Klux Klan. No filme de John Ford, quando finalmente o combate contra os índios ocorre e os passageiros da diligência se preparam para o fim, Hatfield encosta a arma na cabeça de Lucy, que reza desesperada em dramático close-up. O suspense se resolve quando uma flecha atinge o suposto aristocrata e ele deixa cair o revólver. Antes mesmo da intervenção da cavalaria, sua morte trava o gesto que lembra a cena do 
patriarca em Onascimento, um gesto que, como observei, adquire outra conotação, pois agora é outro o estatuto do herdeiro daquela tradição. Embora osíndios, nestefilme, constituam uma alteridade radical, "selvagens", o mundo "civilizado" apresenta suas fissuras e a nação mostra ter problemas que denunciam esses ímpetos de sacrifício diante da ameaça como uma forma de afetação ilegítima.

Ethan, o protagonista de Rastros de ódio, é interpretado por um John Wayne já consolidado como emblema no star system, também encontra seu momento de quase execução da moça branca, em nome de uma pureza da raça cuja defesa é o motivo central de seus empenhos. Ela é a sua sobrinha raptada pelos índios que invadiram o rancho do irmão e massacraram a sua família. O ódio racial é sua marca de começo a fim, pautando sua procura obstinada de Deborah e, em particular, sua conduta quando, anos após o sequestro da menina, ele e Martin, seu parceiro na longa busca e aplicado aprendiz, conseguem o primeiro contato com o grupo indígena que a levou. Passam por mercadores, mas travam um diálogo ríspido. Scar, o cacique que já vimos na cena do rapto de Deborah, porta o medalhão que Ethan havia dado a ela. $O$ confronto é tenso e as mútuas alusões reforçam a relação de espelhamento/rivalidade entre Ethan e Scar. O diálogo não avança, mas os visitantes são conduzidos à tenda do cacique disposto a exibir seus troféus (escalpos). O choque maior, no entanto, se dá quando reconhecem a figura de Deborah, já adolescente, como parte do círculo que serve o cacique (uma de suas mulheres?). "Engolem" a cena em silêncio; a cortina se fecha.

Ethan não perdoa essa nova identidade da moça educada pelos índios. Termina por apontar a arma para a sobrinha quando ela, mais tarde, os procura nas imediações da aldeia para, atormentada, pedir-lhes para ir embora, num misto de aflição por eles e por ela, decidida a permanecer na tribo ("esteé o meu povo"). Martin se põe à sua frente para impedir o tiro, recebendo ordem expressa para se afastar. Colocado o impasse, é novamente uma flecha indígena que ajuda a salvar a moça branca do "sacrifício", atingindo o seu tio no ombro. Ato reflexo, ele dispara a arma sem acertar o alvo, para alívio de um Martin indignado com a ideia fixa de Ethan e atento à missão de proteger sua quase irmã do ódio racial de seu quase tio.

Martin é o mestiço que, lá no início, entrou em cena no rancho de Aaron Edwards, o pai de Deborah, a mostrar seus traços indígenas na destreza de cavaleiro sem sela.É o filho adotivo dos Edwards, um parente que Ethan não aceita, embora o tenha salvado na infância de um ataque comanche. Naquela primeira cena à mesa, sua história se delineou para o espectador, temperada pela reiterada agressão do quase tio. Adiante, após o massacre da família, a rejeição se transformou em contrafeita aceitação cimentada pelos anos de convivência na busca 
de Deborah. O lance traumático do reencontro com ela, já adolescente, leva o tio a "deserdar" a sobrinha em declaração solene: para ele, está morta. O estranho testamento fora de lugar se enuncia em pleno Monument Valley, e sela a nomeação simbólica de Martin como seu único herdeiro. Os opostos terminam por se encontrar a partir do vínculo entre mestre e aprendiz que aqui recebe especial inflexão: Martin, o meio-índio, traz no corpo e nos gestos essa condição, sendo mais humano na lida com os embates próprios ao frontier, em oposição a Ethan, o racista cultor da pureza, figura do ressentimento que parte para uma violência incontida em sua guerra particular, e revela o avesso sinistro do mito americano do novo homem renovado pelos desafios da conquista do Oeste.

Colocada a tópica da pureza racial, The searchers aguça as contradições do guerreiro que encarna a lei do sangue, herói calejado e desgastado pelo tempo. Truculento e vingativo, sua tônica é de solidão, dividido entre a postura reativa associada a um senso pessoal de missão a cumprir e o sintomático silêncio sobre as zonas enevoadas de seu percurso dentro da ordem marcial que jamais abandonou após a derrota do Sul confederado. Na dinâmica do choque de culturas, Ethanéo branco racista que, no confronto, completa sua vingança pela profanação de cadáveres inimigos, adotando seus rituais (como escalpar, por exemplo). Sua dupla face de "conquistador enraizado" no cenário da luta marca uma competência na lida com os desafios do frontier que o faz peça-chave na estabilização do mundo dos pioneiros, mundo com o qual ostenta seu descompasso como figura do enigma em constante movimento.A imagem do nômade se afirma logo na abertura do filme.

Os créditos iniciais desfilam sobrepostos a um design que traz o padrão gráfico de uma parede de tijolos; não se trata da imagem naturalista da parede de madeira que sustenta a casa dos colonos. Remete à ideia de abrigo,éícone de um desejo de vida sedentária que o influxo civilizacional requer. Em contraste, a letra da música evoca a figura do wanderer e traz as perguntas sobre os motivos que o levam a ride away, enfrentar os desafios de um mundo inóspito. Ethan emerge da paisagem como essa figura do cavaleiro errante na primeira cena, esta que se abre com o célebre plano em que, da casa isolada no campo, a porta aberta permite descortinar o vale. Martha Edwards sai para verificar o que se passa e o vê surgir, ainda ao longe. Esse quadro (emoldurado pelo retângulo da porta) dentro do quadro (definido pela posição da câmera dentro da casa) é uma composição-chave que, por sua vez, emoldura o próprio filme: ela voltará com sua carga simbólica no último plano de The searchers, esse que trará a imagem de Ethan fora da casa, a observar o seu interior e a se afastar em definitivo.

O uso da iconografia que atualiza o mito do forasteiro que chega de longe será aqui, no entanto, logo balizado pela definição de uma iden- 
tidade e de um passado que marcam a sua pertinência à família que o recebe de forma a resumir bem esta mescla de intimidade e mistério: depois de um momento de apreensão - quem é? - vem o reconhecimento. Casal e filhos como que compõem um novo quadro ao se posicionar na varanda da casa (lugar de transição) para uma recepção que, no entanto, estará longe de ser efusiva. $\mathrm{O}$ ar de desconforto de Aaron Edwards, seu irmão, e a postura mais terna de Martha, a cunha$\mathrm{da}$, anunciam algo que se confirmará logo adiante. Por ora, o clima se desanuvia pela interação simpática de Ethan com o sobrinho adolescente e as duas meninas, momento da cena simbólica em que levanta Deborah com carinho, para observar seu rosto bem de perto, em verdade a confundindo com Lucy, a irmã mais velha, lapso que descontrai a todos - o tempo passou.

Dissolve-se nessa cena uma parte do mistério gerado por sua figura, seus gestos, sua capa e sua calça reveladora do exército confederado, mas permanece uma zona de sombra quanto a suas andanças depois da Guerra Civil, havendo referência a atividades no México, algo escuso, ações mercenárias. A questão que se insinua nos olhares e na forma do reencontro inesperado é de foro familiar, mas será logo atropelada por um conflito maior gerado pela movimentação dos índios, como em Stagecoach. Esse papel de agressor reservado aos comanches logo no início é a marca da convenção do gênero neste filme de Ford, algo que permanece até o fim, quando se dá a aniquilação da tribo de $\mathrm{Scar}$, fechando os episódios de guerra. O que The searchers traz como intervenção crítica, para um filme de 1956 imerso num ambiente de tensões raciais nas cidades e na paranoia dos brancos, são as zonas de sombra de Ethan-Wayne e, dado mais direto, a referência a episódios de barbárie por parte do exército da União - clara evocação do general Custer e seu massacre de uma aldeia indígena cujo terrível resultado é feito imagem que os protagonistas testemunham em suas andanças.

Ethan está longe de estar só no ódio racial, em efeito partilhado pela maioria dos brancos, homens e mulheres à sua volta, como um sentimento que aflora mesmo quando inesperado, como no caso de Laurie Jorgensen, a "boa moça" a quem a trama reserva o casamento com Martin, ao final, para formar um dos pares fundadores da nova ordem. Como expressão do racismo, Ethan não é exceção, apenas seu ponto-limite que, por isso mesmo, carrega o "fardo" da violência como um pai protetor.

No início da trama, a liderança da comunidade está nas mãos do reverendo Clayton, que comanda a milícia defensora do território, os Texas Rangers. Ele chega ao rancho dos Edwards para avisar da mobilização causada pelo ataque a uma fazenda, obra da tribo de Scar, e convocar os homens para uma expedição punitiva. Uma vez na casa, o reverendo revela a sua surpresa e a tensão gerada pela presença de 
Ethan, de quem não tem boa imagem, mas aceita a sua participação na empreitada. Um dado revelador de lances familiares é sua expressa postura imóvel, a observar ovazio quando desvia o olhar - porque conhece o passado - da cena que vem confirmar o sugerido na abertura: no cômodo ao lado, Martha acaricia a roupa de Ethan, devaneia, traz os sinais de uma paixão pelo cunhado, a quem encontra, em seguida, na mesma sala em que está o reverendo, cuja atitude diz tudo sobre a crônica familiar e a rivalidade entre os irmãos. Insinua-se aí uma perda não superada, algo que tem a ver com essa afetação de Ethan como cavaleiro errante não aquinhoado pela ação estabilizadora da figura feminina, um motivo romanesco medieval recorrente no western.

Hóspede incômodo na casa dos Edwards, ele logo se mostra útil no combate aos índios. Conhece os códigos do inimigo, e sua eficiência na guerra o faz carismático. É o primeiro a perceber a astúcia indígena que trouxe a milícia a seu terreno para deixar desguarnecido o rancho do irmão. Antevê a tragédia. Esta se prefigura na longa imagem de seu rosto em primeiro plano, antes da volta que confirma suas previsões. Diante da casa, sozinho, encara a cena do massacre e seus cadáveres, poupando os demais; em especial Martin, a quem impede de se aproximar da imagem traumática. Após o enterro de seus familiares, parte para a expedição de resgate e punição; não ouve os argumentos dos amigos que tentam impedi-lo de continuar a cadeia da vingança envolvendo a nova geração, incluindo Martin e o noivo de Lucy na tarefa.

A peregrinação pelo território é longa e confusa, seguindo um padrão enigmático que, no plano prático, é uma duplicação do itinerário da cultura nômade do grupo que eles procuram. Em suas andanças, Ethan negocia com os índios, interage com distintas tribos. Inclui em seu percurso passagens sinistras, a exemplo do encontro com jovens perturbadas após passar pela experiência do sequestro, moças que ele rejeita (espelhos de Deborah?). Há passagens bizarras que Martin descreve em suas cartas para Laurie Jorgensen, com um certo humor que denota uma soberba racial, neste caso em sintonia com a de Ethan, destacada a brutal rejeição da moça indígena que, seguindo o código da sua cultura, tomou um episódio de negociação deles com a sua tribo como um trato de casamento com Martin, trato que os brancos não entenderam, e os seguiu para ser agredida e enxotada.

De início caracterizado como figura do contato, da miscigenação que Ethan odeia, Martin consolida, ao longo do filme, a sua identificação com a cultura dos brancos - algo que tem curiosa simetria com a experiência de Deborah, que, por um momento, pareceu consentir com a sua nova condição de comanche. Será o extermínio de sua tribo pelo poder branco que dará ensejo à cena em que ela inverte a sua postura e aceita a "volta ao lar" nos braços de Ethan, ele também foco de uma inversão em que passa da disposição assassina ao afeto paternal 
num instante. Algo que alguns críticos explicam ao atribuir tal desmontagem da máquina racista de guerra à satisfação por ele encontrada na vingança sem limites contra Scar, algo já consumado antes dessa cena controversa do seu encontro com Deborah. Outras leituras apontam a sua memória de Martha como inspiração, pois é ela a figura evocada na peça musical que retorna nesse momento decisivo.

As condições que a história oferece a Martin facilitam seu movimento de integração, selado ao final quando vence a batalha da conquista de Laurie, a filha dos imigrantes que vieram da Escandinávia para partilhar a experiência dos pioneiros. Adaptados às vicissitudes da vida social do frontier, os Jorgensen compõem um contraponto aos Edwards, e ganham espaço na trama quando sua filha vem ao centro da intriga romanesca para compor a face afortunada de Eros nesta ficção de fundação, algo só acessível à geração que emerge no momento decisivo da conquista do território, em contraste com o solitário Ethan, a quem, entre idas e vindas, resta a solidão, não sem antes completar a sua missão vingadora que será viabilizada por uma convergência especial.

Essa convergência se dá quando elee Martin, mais uma vez devolta a casa, encontram a vida do grupo já mais pontuada de uma sociabilidade que inclui os rituais festivos que tanto marcam os filmes de Ford como sinais de uma nova comunidade em construção. O retorno de Ethan continua um fator de tensão, pois seus excessos na violência, certa feita dirigida a brancos, o fizeram um perseguido, mas o costume local ainda relaxa suas regras para que ele possa partir com o exército na carga final à tribo de Scar, novamente pelas redondezas. Alei da família e o interesse maior do Estado representado pelo exército se unem nesta geografia do West para consolidar a vitória dos brancos e a futura incorporação mais estável desse território ao marco nacional em expansão.

No ataque, selando sua condição de herói ascendente, é Martin quem mata Scar. Ethan, tendo chegado tarde, o escalpa. Lance seguinte, o tio persegue a sobrinha, que corre apavorada, pois espera a mesma violência do encontro anterior em que por pouco não levou o tiro. A imagem do encontro vem dar uma ressonância simbólica para o embate: quando ela tenta se esconder numa gruta, a câmera se posiciona dentro desta, focalizando a cena com o recorte irregular-natural da fenda que constitui a entrada "selvagem" desse espaço obscuro, tudo em oposição aos planos inicial e final de The searchers, quando o contraste entre abrigo e natureza se faz no recorte retangular do batente da porta da casa da família. Martin corre para intervir, mas, antes que alcance Ethan, este já tem domínio da cena e observa a sobrinha exausta, caída a seus pés. É o momento da inversão espetacular, do "golpe de teatro" radical: Ethan assimila a nova Deborah e a levanta com carinho, repetindo o seu gesto lá do início do filme, fechando o ciclo e reinscrevendo a moça no espaço da família. 
Por sua vez, Deborah entra em sintonia com a inversão de Ethan e reassume nessa cena a identidade racial que a encaixa muito bem na tonalidade de "volta ao lar" que marca a sequência final, momento em que o tio a entrega à família Jorgensen para um reencontro com o mundo da infância de que participam figuras-chave da vizinhança. Com ar solene, os Jorgensen a conduzem, acompanhados de Martin e Laurie. Todos entram na casa, que simboliza, nesse final, o futuro ligado à ocupação estável do território, com a derrota da alteridade condensada ao longo do filme na figura de Scar. Só Ethan, embora retorne vitorioso, permanece fora da casa. Uma autoexclusão que recebe o acordo tácito das famílias reunidas, pois ninguém fala nada, nem sequer dá sinais de qualquer atenção ao fato. Ele assume o seu não lugar no futuro melhor que se anuncia. $O$ mesmo recorte da porta aberta traz agora a imagem de sua solidão de herói alquebrado que observa o interior (para nós, fora do campo visível) e logo se retira. Levou ao limite a sua intervenção num mundo que mudou e não mais o absorve como um dos seus, embora ele tenha sido necessário nas tarefas da transição.

Se há, em No tempo das diligências e em Rastros de ódio, a sugestão da clássica figura do herói que vem intervir no destino da comunidade e se retirar, vale lembrar que em nenhum deles, e tampouco no caso de $O$ homem que matou ofacinora, encontramos a figura solitária do gunfigther errante, forasteiro sem conexão com os personagens com quem vai interagir ou com o local em que intervém. Não temos aquele protagonista de uma estrutura mítica circular que supõe a ação justiceira do presente como repetição de aventuras de mesmo teor no passado. Aqui, quando ele se afasta, não há nenhum sinal de continuidade do ciclo num futuro que iria repor a mesma ordem de coisas dentro da qual seu heroísmo faria sentido. Rompendo o círculo, há um tempo que avança e eclipsa a sua figura. Ringo tinha um histórico na região; sua instabilidade, como fugitivo, tinha razões claras e se dissolvia no fim. Sua união com Dallas, avalizada pelo xerife, era a marca definitiva do papel da mulher na composição da utopia agrária e da vida sedentária. No caso de Ethan já não há mais tempo para encontros estabilizadores ou um novo rancho mais adiante. Resta para o herói da transição um perfil que o filme expõe a uma reflexão crítica, ressaltando a conjugação de brutalidade, racismo e dedicação à guerra de conquista. Tal reflexão, por seu lado, não descarta o carisma da figura marcial cultivado em chave romanesca, apesar das restrições que lhe são feitas. No final, reitera-seesse movimento duplo quando ele passa por um julgamento implícito pela atitude da comunidade em fase de consolidação nesse território em que o Estado, pela ação do exército, dá sinais de vida, ainda que incipientes, num estágio avançado da guerra de extermínio.

É essa travessia, da guerra à estabilização do território, encarnada na busca e salvação da menina sequestrada, que define o lugar de 
[6] Ver Slotkin, Richard, op. cit., pp. 10-16.
The searchers na mitologia do western. Enquanto ficção de fundação, $o$ filme retoma um motivo recorrente na literatura do período colonial nos Estados Unidos, quando, desde cedo, as narrativas de sequestro e cativeiro de moças brancas pelos povos indígenas se tornaram uma vertente de sucesso ao longo do século XVIII, antes da emergência do mito do West ${ }^{6}$.

Curiosamente, este é um motivo recorrente que não se reduz ao cinema hollywoodiano, tendo sido central em ficções de fundação que introduziram essa dimensão épico-monumental no cinema do início do século, notadamente no filme-marco Cabíria (1914), um dos maiores clássicos do gênero peplum (filme italiano de época centrado em aventuras vividas na Roma Antiga). Realizado por Giovanni Pastrone, com a colaboração de Gabriele D'Annunzio no roteiro e nos letreiros didático-poéticos, traz a complicada trama que fez confluir a vitória dos romanos nas Guerras Púnicas e a consolidação do Império com a salvação da jovem Cabíria, filha de nobres romanos. Quando criança, ela fora sequestrada pelos fenícios logo após uma erupção vulcânica que destruíra o palácio familiar e a fizera órfã. Levada para Cartago como escrava, é resgatada, muitos anos depois, por Fulvio Axilla, patrício romano que participa da invasão vitoriosa de Cartago que sela a hegemonia de Roma no Mediterrâneo. O Marenostrum é o palco aureolado da celebração da vitória de Roma (Polis) e da felicidade do par amoroso, Fulvio e Cabíria (Eros). De Pastrone, esse motivo alegórico encontrou resposta em Griffith, passando daí ao western, e em particular para a apropriação mais reflexiva de John Ford.

\section{ATOS DE EXCEÇÃO: O FUNERAL QUASE SECRETO DO HERÓI DESCONHECIDO}

Realizado em 1962, O homem que matou o facínora é mais radical na revisão histórica do gênero. Faz o cotejo entre dois momentos da formação nacional, trazendo uma nova variante da ficção de fundação e seu modo de dar conta da experiência de consolidação da lei da Polis. A experiência do frontier já não destaca o confronto com o indígena, mas o conflito entre grandes proprietários de terras, pequenos agricultores e citadinos. O mundo em torno de Shinbone, a cidade sede do drama, está marcado pelo debate entre o reivindicar um lugar na União como estado da federação ou permanecer como território anexo, o que significa, do ponto de vista dos criadores de gado, espaço livre para as pastagens e para a permanência de seu mandonismo de proprietários sem interferência de um marco legal.

De qualquer modo, a vida política de Shimbone já constitui uma esfera pública em que há lugar para a imprensa e para a introdução de uma incipiente escola pelo herói civilizador típico a um estágio mais avançado da conquista do West. A ação do homem dos livros, 
o Ramsom Stoddard recém-chegado do Leste, no entanto, não seria bem-sucedida sem a parceria do homem das armas, Tom Doniphon, o herói da transição, que ganha aqui uma feição bem distinta. Ao contrário de Ringo, não tem nova chance e não recebe do polo de Eros a estabilização na figura da mulher desejada. Embora partilhe com Ethan a solidão final e o não lugar no futuro, seu percurso envolve a afirmação de outros valores e uma particular virtude expressa na renúncia e na contenção que estão nos antípodas do ódio racial daquela figura sombria demais, notável expressão de contradições em geral recalcadas no gênero.

A experiência de Tom Doniphon se dá em novo contexto do processo da modernização. É um exemplo mais nobre de herói da transição, o que não impede que seu eclipse se dê como radical condenação ao esquecimento, condição que o filme trabalha num tom elegíaco singular com uma forte tintura de melancolia. Sua saída de cena é observada de um ponto futuro, quando se pode constatar de forma mais nítida como seu ostracismo está marcado pelo que se reconhece como uma impostura necessária à vitória da nova ordem. Desloca-se a forma da construção da figura do não lugar, pois a reflexão sobre o apagamento do herói, antes de ser uma prerrogativa da narração, é já um movimento assumido de modo explícito pelos personagens que a assumem nesse tom de melancolia e desconforto que se ajusta a um reconhecimento de suas qualidades não raro encobertas pela truculência e pelo desajeito na esfera dos rituais de sociabilidade.

O último passo da trilogia de Ford repõe o espelhamento entre início e fim que marca The searchers, desta feita entre a chegada à cidade do casal protagonista - Ramsom Stoddard e sua esposa Hallie - vindo de trem da capital do país, e sua partida de retorno a Washington ao final. Estamos, no final do filme, num momento histórico em que o avanço da urbanização e da unificação dos Estados Unidos pela rede de linhas férreas já deslocou os termos da utopia agrária (o deserto transformado em jardim pelo cultivo em pequenas propriedades). A consolidação de um capitalismo industrial não elimina os sonhos de agricultura forte e essencial na economia, mas já começa a desfazer o culto à pequena propriedade que o projeto de expansão, e mesmo o seu marco legal, propiciou em meados do século XIX, quando deslanchou a conquista do Oeste. Já são outros os termos do avanço do agribusiness ao lado da urbanização e da nova ordem econômica que alcançará total hegemonia no século XX, com lances dramáticos de crise social e destituição dos agricultores que o próprio cinema de John Ford, em chave realista, focalizou em filmes como Caminho áspero (Tobacco Road, 1941) e Vinhas da ira (1939), este centrado na emigração para a Califórnia dos despossuídos doMidwest (Oklahoma), uma emigração já sem as mesmas conotações heroicas da época celebrada pelo western. 
$\mathrm{Na}$ abertura, a chegada inesperada de Ramsom Stoddard, cultuado como herói da transformação do território em estado da federação, primeiro governador desse estado e agora célebre senador da república, atrai o repórter do Shimbone Star, o jornal fundado lá nos tempos heroicos pelo iluminista Peabody, outra figura ímpar na história da cidade. A pauta é uma entrevista em que se impõe a pergunta: o que o trouxe da capital do país à longínqua Shimbone, e por que chegou incógnito? O senador explica que veio para um funeral, assunto privado, e pede para ser deixado em paz. O dono do jornal, também presente, afirma que está no seu direito reiterar a interrogação pelo defunto, cuja importância vem atestada pela ilustre visita. Stoddard hesita e olha para a esposa, Hallie, que sinaliza sua concordância. Ele aceita, então, contar a história do homem cujo corpo está lá no caixão velado apenas por Pompey, seu fiel criado ao longo da vida.

A narração do senador só começa depois de se dirigirem para um depósito de itens em desuso onde Stoddard encontra a diligência que verifica ser aquela mesma que o trouxe para o Oeste algumas décadas atrás. Ela se parece com a que vimos na viagem entre Tonto e Lordsburg, em Stagecoach. Ele sacode a poeira, aviva a memória e mergulha no passado, começando pela experiência de passageiro da diligência vinda do Leste, quando foi vítima do assalto do bando de Liberty Valance, que simbolizava a violência da velha ordem dos criadores de gado e seus capangas. É simbólica a surra que o bandido lhe dá com o chicote, depois de ver sua bagagem de advogado repleta de livros sobre leis: "Vou lhe mostrar a lei do West". Desacordado, ele é encontrado por Tom Doniphon, que o socorre e o traz para Shimbone, entregando-o aos cuidados de Hallie, sua paixão, e seu pai, dono de um restaurante local.

Definem-se aí os polos do conflito entre a lei das armas e a lei dos livros, com a correlata oposição entre Liberty Valance, o gunfighter do mal, e Doniphon, o gunfighter do bem, pois este assume o papel de protetor do recém-chegado como uma espécie de missão que acabará comprometendo seus projetos, em especial o do casamento com Hallie. De início, parece não se dar conta de nenhuma ameaça, talvez porque não leve a sério a figura de Ramsom como macho rival, talvez porque calcule que ajudá-lo é uma forma de afirmar sua condição de fiador do bem na cidade de Shimbone e conquistar Hallie de vez. Com o tempo, a sua combinação de hegemonia no plano das armas e de intuição do que é de justiça, somadas à sua convicção do bom efeito dessas duas qualidades na esfera de Eros, é superada pelos fatos. Perde terreno na conquista de Hallie, encantada com a república das luzes que o recém-chegado lhe franqueia: alfabetização e bancos de escola onde ele ensina a um pequeno grupo a ordem republicana e o espírito das leis, uma civilidade no trato que termina por prevalecer no cotejo dos valores que mobilizam a moça, dividida entre o mundo de inte- 
ração direta com a natureza em que se sente enraizada e o mundo da cultura mediado por abstrações e valores que, cada vez mais, fazem sentido para ela. Os movimentos de Hallie, gradualmente percebidos por Doniphon, não afetam a noção que ele tem do que deve fazer para viabilizar a vitória dos livros sobre as armas, percurso no qual assume diferentes papéis, seja o de bem-humorado professor do desastrado advogado no manejo do revólver, seja o de seu salvador na hora fatal.

Nesse terreno pouco propício ao poder das palavras, Ramsom Stoddard não está só. Antes dele, Peabody, o jornalista engajado em campanhas contra as forças do atraso que patrocinam a violência, já cuidava do avanço das luzes sobre Shimbone. Corajoso, militante, traz os sinais do desgaste da luta e lembra Doc Boone, o médico de Stagecoach, nos lances de uma filosofia embalada no bom copo, mas sua ironia não se une ao desencanto pela civilização. Encarna o herói combativo da imprensa, e seu apostolado liberal termina por lhe custar a vida. Parceiro do advogado em seus confrontos, solitário nas noites de trabalho na sede do jornal, frágil diante da violência, ele é o alvo mais urgente para os patrões de Liberty Valance. Este invadeo jornal, espanca Peabody e termina por levá-lo à morte. A indignação do advogado quando chega à cena do crime funciona como ponto de ignição de uma insensatez que o faz cair na armadilha, partindo para um duelo com Liberty Valance em plena rua, em frente ao saloon, como a tradição dos gunfighter solicita.

A moldura composta para a cena, o testemunho ocular de todos os presentes e a própria convicção de Stoddard convergem na direção de um inverossímil que passa da conta. Há o consenso de que o advogado operou o milagre de, no maior desajeito, vencer o duelo, algo que o espectador observa reticente, embora refém do ponto de vista construído para a cena e do residual efeito das regras de verossimilhança do gênero. De qualquer modo, para ele não romper o contrato de suspension of disbelief diante do disparate, resta-lhe conferir à narrativa o crédito de uma interrogação a ser resolvida, algo já sugerido pelas expectativas de revelação presentes na postura inicial do senador, cuja entrevista é, afinal, a mediação desseflashback.

Foi a celebridade al cançada por tal façanha que o galgou à condição de forte candidato como representante de Shimbone na convenção do território que deveria votar pela petição para se tornar estado, passar de uma ordem instável em que prevalece o poder do mais forte para o marco legal da república. Na convenção, acusado de assassino pelos criadores de gado, tem o sentimento de culpa potencializado e ameaça abandonar a cena e sua candidatura.É o momento da última e decisiva intervenção de Tom Doniphon, que o chama de lado para revelar, a elee a nós, a verdade daquele duelo. Torna tudo mais plausível descrevendo a sua ação clandestina que sincronizou o seu tiro de rifle (sem risco de erro) com o dos contendores, tiro disparado da viela escura em que 
[7] Nesse novelo de afetos tecido por Hallie ganha expressão uma dinâmica de superação e permanência acentuada no texto de Davi Arrigucci, acima citado, com que dialogo aqui: o mote é a construção do jardim, mas o deserto permanece. $O$ passado, ou a natureza dentro de nós, não se anula, dispondo-se em camadas. ele se fazia invisível. Liquidou, assim, Liberty Valance sem a licença do duelo cara a cara, numa medida de exceção ao seu código de gunfighter que traz a sua simetria com o ato de exceção de Stoddard, que, na contramão ao espírito das leis, assumiu o papel clássico procurado por Doniphon. Este, que desafiara frontalmente Valance em outra cena, é reduzido a uma intervenção em tocaia que o deslustra, mas assumida em nome do Bem e da sua adesão ao projeto civilizatório de Stoddard.

Serviço completo. Consolidação de sua ruína. Quando, mais tarde, ele decide intervir ainda uma vez na história para liberar o advogado da culpa e intimá-lo a voltar à assembleia e retomar a sua candidatura, já sabe que isso arremataria a sua perda de Hallie, de que ele havia se dado conta lá no episódio da morte de Valance, quando chegara ao restaurante e surpreendera os afagos da moça a cuidar do advogado ferido, algo além de um zelo de enfermeira improvisada. Estava selada a união de Hallie com o homem dos livros. Eestava deflagrada a sua crise pessoal, que culminou no seu gesto de tocar fogo na casa por ele construída para abrigar a sua futura vida com ela. Essa casa era a cristalização de uma nova etapa em sua vida e mesmo na história da propriedade localizada no limiar do mundo dos homens, com sua feição quase selvagem na vegetação, uma permanência simbólica do deserto, ponto de origem e seiva identitária.

Doniphon sempre levou consigo esta condição de ícone maior da terra que condensa seus valores, os mesmos que nunca abandonaram o coração de Hallie, como se evidencia no futuro, tempo em que as estradas de ferro substituíram as diligências, e em que ela retorna com o marido para o funeral do amor descartado, mas não de todo superado. Quando Stoddard, no início do filme, échamado para a entrevista, ela vai visitaras ruínas do lar que lhe estava destinado, não foram o atropelo dos tempos e sua escolha do homem dos livros. Nessa visita, conduzida pelo antigo xerife, cuja expressão sinaliza um saber que realça a cumplicidade de afetos, o filme leva ao limite o olhar melancólico presente desde sempre e, em especial, quando esteve diante do caixão na funerária. Uma vez no rancho, ela colhe a flor do cacto que tudo resume da sua relação com o passado: sua juventude, seus sentimentos $\mathrm{e}$ Tom, sua referência maior.E é em torno desse símbolo que se compõem sintomáticos jogos de olhares: do amigo que conhece toda a história, no momento mesmo em que ela colhe a flor, e de Ramsom no momento em que, depois da entrevista, ao voltar para o velório, percebe a flor de cacto depositada no topo do caixão a marcar a lembrança e a homenagem póstuma7.

Se o marido contou a verdade disposto a desmontar o mito que viabilizou a sua carreira política, ela refez o elo afetivo nessa celebração do herói da transição que tornou o futuro do casal possível, e foi decisivo para a "limpeza da cidade" e a consequente implantação da nova ordem onde ele não teria lugar, pois o caminho da civilização de Shimbone passava pelo seu apagamento. 
Se Ethan era o ressentimento e a zona de sombra, no limite do insuportável, Tom é o bom sujeito que recolhe um título de nobreza como figura do sacrifício, dono de um senso de contrato social que o mobiliza na batalha de Stoddard, embora tenha zelado pelos seus direitos de propriedade ao vir retirar seu criado Pompey da sala de aula em que o advogado falava de igualdade perante a lei. E embora tampouco se importasse com uma situação que o filme sinaliza de forma discreta: no momento da assembleia que discute a questão do território no bar da cidade abarrotado, Ford insere um plano de Pompey isolado, sentado num canto em plena rua; não há lugar para um negro na assembleia, a menos que cumpra o papel de escudeiro armado do patrão se uma ameaça se evidencie na cena. Essa era a tônica da relação de Doniphon com seu criado, um curioso exemplo da dominação cordial que, enfim, se entende no contexto, pois acoplada a uma ausência de direitos inscrita nas regras da vida do território.

Encerrada a viagem de tributo ao herói do passado, com tudo o que ela trouxe de interrogação para o casal Stoddard, a atitude dos dois na viagem de retorno a Washington indica o acordo tácito e o respeito pelo que tal volta ao passado significou em sua vida. Feita a pergunta (quem pôs a flor do cacto em cima do caixão?) e dada a resposta (fui eu), Hallie e Ramsey, sentados no trem, não se olham, não consumam o eye contact. Seguem em seus devaneios atravessados pela fala do marido, que comunica seu desejo ainda vago de aposentadoria e retorno ao mundo dos cactos, um misto de nostalgia pessoal referida a uma fase de sua vida e de respeito pelo sentimento de Hallie, uma vez que a hipótese de retorno favoreceria uma vida mais reconciliada. É o que ela sempre quis. Essa viagem ao passado induzida pela morte do herói esquecido deu ressonância a embates e perdas que projetaram esta tintura melancólica no campo de Eros, pois temos aqui uma ficção de fundação que desloca o esquema mítico tradicional, talvez não tanto porque revele a farsa da versão oficial que sustenta a ascensão política de um ícone da civilização, mas porque introduz uma fissura radical na potência encarnada no casal exitoso cujo percurso se fez em sintonia com o avanço da história, mas cuja união só exibe momentos da paixão terna que, entre outros impulsos, se alimentou, lá atrás, da adesão a um mundo futuro a construir, mundo cuja consolidação dependeu daquilo mesmo que eles recusam como forma de administração da justiça: a violência eficiente derivada da competência de um gunfighter alimentado por uma intuição muito sua, como é típico no cinema de Ford, que lhe permite ficar do lado certo. Agora, na viagem de retorno, a paixão terna se alimenta do reencontro com o passado que tem sua expressão mais cabal no mergulho de Hallie no deserto ainda presente, embora a natureza não conte mais com a sensibilidade de citadinos menos atentos às suas virtudes e tenha seu principal representante 
[8] Robert Pippin, Hollywood westerns and American myth: the importance of Howard Hawks and John Ford for political philosophy. New Haven: Yale University Press, 2010, pp. 69-101. relegado ao absoluto esquecimento, de que nem mesmo a "confissão" de Stoddard vai conseguir retirá-lo.

Trabalha-se aqui, na intimidade do casal, a mesma gama de sentimentos expressa na tonalidade da mise-en-scène e na retomada da imagem em preto e branco como suporte para um olhar retrospectivo que assume a elegia de um mundo que sabe condenado pelo tempo, problemático em sua feição social, mas cenário das lutas decisivas que uma visão teleológica da formação nacional celebra como elo necessário, o que Ford também não deixa de fazer, num movimento que funde o elogio da superação e a nostalgia.

Robert Pippin ${ }^{8}$ insiste nesse ponto de encontro entre o sentimento de distância e diferença diante de um passado, cuja superação se considera necessária e bem-vinda, e o sentimento de fascínio e nostalgia por esse mesmo passado. Procurando conciliar perdas e ganhos, a construção pública de um imaginário sedutor vem dar expressão a essa duplicidade que envolve a idealização do ritual da violência encarnada nos gestos de personagens fora do comum e o temor de quem, embora em terreno seguro, percebe o que está implicado na realidade que a ficção transfigura. A ironia deste meta-western de John Ford é levar ao extremo a distância entre a versão oficial (a idealização expressa na lenda) e o teor do acontecido, de modo a comprometer o herói civilizador e revelar como a mentira é algo essencial em sua vida. Após tantos anos, quando ele julga imperativo desfazer o equívoco, acaba encontrando a resistência do homem de imprensa que vem zelar pela função política da lenda, depósito de valores que interessa preservar. Refreando o ímpeto do jovem repórter amante da verdade e ansioso em publicar tal furo de reportagem, o dono do jornal rasga as anotações da entrevista e arremata com a célebre frase: "Aqui é o Oeste, senhor; quando a lenda se torna fato, imprima-se a lenda".

Tal frase culmina o movimento de reflexão sobre o western como gênero, e sobre as relações entre o mito e a história, a realidade e a lenda, restando ao espectador analisar as implicações dessa sentença que diz respeito a um imaginário que a indústria do cinema e o western em particular alimentaram a partir do núcleo duro dos filmes de gênero mais convencionais, mas que John Ford e outros cineastas, vez ou outra, trabalharam de outra forma. Na trilogia aqui em foco, verifica-se uma dose crescente de reflexão e consciência crítica que tem seu ponto de formulação explícita em O homem que matou o facínora, não tanto porque haja um impulso de negar a legitimidade da presença de tal imaginário na tradição do western, mas porque, reconhecendo a sua relação com a própria constituição do gênero, o filme faz o duplo movimento de se valer da capacidade de sedução do que é canônico dentro dele e, ao mesmo tempo, fazer seus esquemas conviver com essa desmontagem no lance final. 
Ramsom Stoddard sabe que a violência competente construiu o alicerce do seu triunfo que encarna a consolidação da ordem constitucional e, ao mesmo tempo, o recalque de um dos seus alicerces, recalque que uma indústria editorial do século XIX, acrescida da cinematográfica no século XX, transformou em pressuposto do imaginário hegemônico de uma ordem liberal no mascaramento das reiteradas medidas de exceção apoiadas na violência, incluindo a incorporação do mito dofrontier na construção de novos cenários de expansão e conflitos próprios à potência imperial9.

$\mathrm{O}$ enunciado do jornalista não diz respeito apenas à regra de formação do western como gênero. A frase "this is the West", ouvida nas salas de cinema mundo afora, dá ensejo a uma projeção de seu lema para outras esferas de produção de imaginário ligadas a confrontos, dando ensejo a uma reflexão sobre o que está aí implicado no plano político, dado que a intervenção dos Estados Unidos no contexto de guerras, ainda coloniais, e de golpes de Estado, tudo temperado pela Guerra Fria, marcou o momento em que o filme circulou nos anos $1960^{10}$.

Posto o enunciado, o epílogo do filme de John Ford se volta para a forma como ele ressoa na experiência de Ramsom Stoddard, absorto na assimilação de todo o episódio e seu efeito na sua vida com Hallie. Mergulhamos no universo do casal, no qual rebate o desconforto do senador, que parece observar de uma forma mais incômoda a sua condição, depois de ver o que poderia ser uma confissão reparadora se reduzir a um pretexto para que o dono da notícia enunciasse um princípio a ser seguido pelos construtores da memória, princípio que mostra a sua força nas palavras do homem comum que atende o casal no trem em sua última cena, orgulhoso em servir o herói do famoso duelo, "o homem que matou Liberty Valance".

O ponto-chave - e aqui retorno à questão do carisma dos homens de ação cuja violência competente incide de forma decisiva nessas tramas — está na forma como, consideradas as duas figuras que se complementam na viabilização do futuro, o objeto da redenção elegíaca é o herói que encarna os códigos marciais cuja indispensabilidade se faz um princípio na trilogia. Ressalvada a diferença de perfil e de valor que distancia os protagonistas dos três filmes, o que lhes é comumé a posse de intuições e saberes que os orientam no mundo prático e na violência tomada como necessária. Há nuances e contradições, mas a mise-en-scène reforça a sua feição carismática e seu papel na construção de uma nova ordem da qual serão excluídos por obra de tramas cada vez mais complexas que encontram sua versão final justamente na variante em que a ironia incide com maior intensidade no destino do herói atropelado pela história.

IS MAIL XAVIER é professor da Escola de Comunicações e Artes da Universidade de São Paulo.
[9] Citando Walter Benjamin, Marcio Seligmann analisa a violência fora da lei do herói - com referência ao western e ao cinema brasileiro que trata da guerra do tráfico - em sua conexão com um dado estrutural do poder, notadamente quando este precisa de inimigos (externos ou internos): o "estado de exceção". Ver Seligmann, Marcio. "Violência e cinema: reflexões sobre o dispositivo trágico no cinema brasileiro hoje". Grumo, $\mathrm{n}^{\circ} 7$, dezembro/2008, pp. 56-654, 〈http://www.salagrumo.org/notas. php? notaId $=59$ >.

[10] Richard Slotkin aponta, em seu livro, a forma como John Kennedy se apropriou do mito expansionista do frontier em sua campanha para a Presidência, trabalhando a Guerra Fria e a emulação, naquele momento dramática, com a União Soviética na corrida pela conquista do espaço como The New Frontier. Ver op. cit. supra, pp.1-5.

Recebido para publicação

em 27 de outubro de 2014.

\section{NOVOS ESTUDOS}

CEBRAP

100 , novembro 2014

pp. 171-192 